Ikuko Miyawaki MD, *

Kumi Nakamura MD, ${ }^{\dagger}$

Bencharatana Yokubol MD,

Rie Kitamura MD,

Kenjiro Mori MD FRCA

\title{
Suppression of cyclic guanosine monophos- phate formation in rat cerebellar slices by propofol, ketamine and midazolam
}

\begin{abstract}
Purpose: The nitric oxide (NO)/cyclic guanosine monophosphate (cGMP) system is involved in glutamatergic neurotransmission. The current study determined the effects of propofol, ketamine and midazolam on rat cerebellar cGMP formation, attempting to clarify whether the effect was due to suppression of NO-cGMP system or to direct interaction with glutamatergic receptors.
\end{abstract}

Methods: Cerebellar slices, obtained from six- to eight-day-old Wistar rats, were pretreated with propofol $(10 \mu \mathrm{M}-1 \mathrm{mM})$, ketamine $(10-100 \mu \mathrm{M})$ or midazolam $(1-100 \mu \mathrm{M})$ for $30 \mathrm{~min}$. and then stimulated with L-giutamate (3 mM), N-methyl-D-aspartate (NMDA $0.1 \mathrm{mM}$ ), kainate $(0.1 \mathrm{mM})$ or sodium nitroprusside (SNP, $0.3 \mathrm{mM})$ ( $n=5-1 \mid$ for each group). The levels of CGMP were determined by radioimmunoassay.

Results: None of the anaesthetics studied altered CGMP levels when no stimulant was given. Propofol (10 $1 \mathrm{M}-1 \mathrm{mM})$ suppressed L-glutamate-, NMDA-, kainate- and SNP stimulated CGMP formation in a concentrationdependent manner, the sensitivity to propofol was in the order of NMDA > kainate > L-glutamate, SNP. Ketamine $(10-100 \mu \mathrm{M})$ suppressed L-glutamate- and NMDA-stimulated CGMP formation, but did not suppress kainate- or SNP-stimulated CGMP formation. Midazolam (10-100 $\mu \mathrm{M})$ did not affect NMDA-, L-giutamate- or SNP-stimulated cGMP formation, but suppressed kainate-induced formation.

Conclusion: The inhibitory effects of propofol, ketamine and midazolam on CGMP formation in rat cerebellar slices are due mainly to interaction with receptors for excitatory amines, and not due to the suppression of nitric oxide synthase or guanylate cyclase activities.

Objectif : Le système monoxyde d'azote (NO)/monophosphate de guanosine cyclique (CGMP) participe à la neurotransmission glutamatergique. La présente étude recherchait l'influence du propofol, de la kétamine et du midazolam sur la formation cérébelleuse de CGMP, en essayant de préciser si cette influence résultait de la suppression du système NO-cGMP ou d'une interaction directe avec les récepteurs glutamatergiques.

Méthodes : Des tranches de cerveau prélevées sur des rats Wistar âgés de six à huit jours ont été prétraitées avec du propofol $(10 \mu \mathrm{m}-1 \mathrm{mM})$, de la kétamine $(10-100 \mu \mathrm{M})$ ou du midazolam $(1-100 \mu \mathrm{M})$ et ensuite stimulées avec du L-glutamate (3 mM), du N-méthyl-D-aspartate (NMDA, 0,1 mM), du kainate $(0,1 \mathrm{mM})$ ou du nitroprussiate de sodium (SNP, 0,3 mM) $(n=5$ pour chaque groupe). Le radio-immunodosage a senvi à déterminer le niveau de cGMP. Résultats : En absence de stimulus, aucun des anesthésiques n'a modifié les niveaux de cGMP. Le propofol (10 $\mu M-m M)$ supprimait la formation de CGMP stimulée par le L-glutamate, le NMDA, le kainate et le SNP proportionnellement à la concentration. La sensibilité au propofol s'établissait dans l'ordre suivant NMDA > kainate $>$ L-glutamate > SNP. La kétamine (10-100 $\mu \mathrm{M})$ supprimait la formation stimulée par le NMDA de L-glutamate et de CGMP mais ne supprimait pas la formation de CGMP stimulée par le kainate et le SNP. Le midazolam ( $10-100 \mu M)$ n'affectait pas la formation de CGMP stimulée par le NMDA, le L-glutamate et le SNP mais supprimait la formation induite par le kainate.

Conclusion : Linfluence inhibitrice du propofol, de la kétamine et du midazolam sur la formation de CGMP dans les tranches cérébelleuses de rats est principalement causée par l'interaction des récepteurs des amines excitateurs et non par la suppression de la synthase du monoxyde d'azote ou à l'action de la guanylate cyclase.

From the Department of Anesthesia, Kyoto University Hospital, Sakyo-ku, Kyoto 606-01, Japan.

Present Addresses: *Department of Anesthesia, Kobe City General Hospital, †Department of Anesthesia, Kyoto City Hospital, "and IDepartment of Anesthesiology, Siriray Hospital, Mahidol University.

Supported in part by Grant-in-Aid for Scientific Research from the Ministry of Education, Science and Culture, Japan, (No. 07457355) and Research Grant for Women from ESSO-Sekiyu, Japan. Presented in part at the Annual Meeting of the ASA, Atlanta, October 1995 Address correspondence to: Dr. I. Miyawaki, Department of Anesthesia, Kobe City General Hospital, 4-6, Minatojima-Nakamahchi, Chuo-ku, Kobe, 650, Japan.

Accepted for publication August 14, 1997.

CAN J ANAESTH $1997 / 44: 12 /$ pp 1301-1307 
$\mathrm{N}$ ITRIC oxide (NO), first defined as endothelium-derived relaxing factor, ${ }_{2}^{1-3}$ acts in the central nervous system (CNS) as an intercellular and intracellular messenger molecule. ${ }^{4,5}$ In the glutamatergic system, activation of glutamate receptors increases intracellular calcium. This activates NO synthase (NOS) resulting in increased production of NO. Nitric oxide diffuses into target cells where it activates guanylate cyclase (GC) to increase cyclic guanosine monophosphate (cGMP) levels (Figure 1). This pathway may be involved in mechanisms such as the establishment of CNS plasticity, including memory and central sensitisation to pain perception. ${ }^{6}, 7$ Glutamate receptors are classified as $\mathrm{N}$-methyl-D-aspartate (NMDA) receptors, non-NMDA receptors that include $\alpha$-amino3-hydroxy-5-methyl-4-isoxazolepropionic acid (AMPA) and kainate receptors, and metabotropic receptors. Activation of both NMDA and non-NMDA glutamate receptors activates NOS. ${ }^{8,9}$ In contrast, sodium nitroprusside (SNP) does not activate NOS, but liberates NO or NO-related compounds to activate GC, thereby increasing cGMP levels (Figure 1 ). ${ }^{10}$

General anaesthetics suppress endothelium-dependent relaxation and acetylcholine-induced, NO-mediated, cGMP formation in the vascular system. ${ }^{11-16}$ Moreover, suppression of NOS and GC activity by general anaesthetics has been demonstrated. ${ }^{17,18}$ However, anaesthetics interact with glutamatergic receptors. It should be clarified, therefore, whether the suppression of the glutamatergic system by anaesthetics is an action

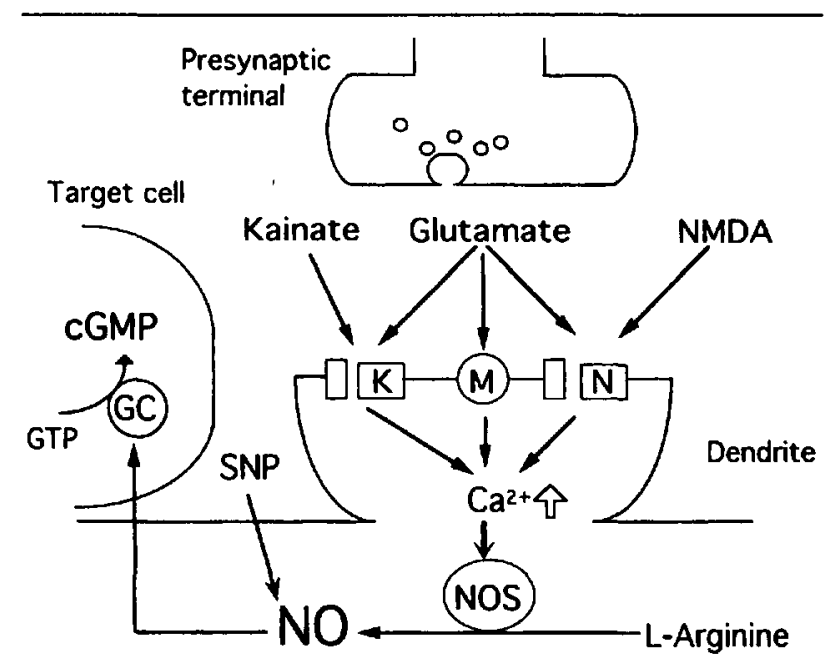

FIGURE 1 The nitric oxide (NO)-cyclic guanosine monophosphate (cGMP) pathway in the central nervous system. N, Nmethyl-D-aspartate (NMDA) receptor; K, kainate receptor; $M$, metabotropic receptor; NOS, NO synthase; SNP, sodium nitroprusside; GTP, guanosine triphosphate; GC, guanylate cyclase. on the glutamate receptor-channel complex, or a direct effect on the NO-cGMP system such as suppression of NOS or GC. Our previous study suggested that the suppressive effect of thiopentone on cerebellar cGMP formation was mediated by suppressed GC activity. ${ }^{19}$ The present study examined the effects of the commonly-used intravenous anaesthetics, propofol, ketamine and midazolam, on L-glutamate-, NMDA-, kainate- and SNP-induced cGMP formation, in an attempt to identify the site(s) of action of these agents. We used cerebellar slices of infant rats because this tissue contains abundant glutamate receptors. ${ }^{20}$

\section{Methods}

Wistar rats, aged six to eight days, were sacrificed according to the Guideline of Animal Experiments of Kyoto University, and the cerebella were quickly harvested. The cerebella were rinsed and then bathed in Krebs' bicarbonate solution at $4^{\circ} \mathrm{C}$. Using a bow cutter, $0.4-\mathrm{mm}$-thick slices were obtained from each cerebellum. The slices were then incubated at $37^{\circ} \mathrm{C}$ in Krebs' solution, aerated with $\mathrm{O}_{2} 95 \% / \mathrm{CO}_{2} 5 \%$. The $\mathrm{pH}$ of the aerated solution was $7.40 \pm 0.05$.

First, dose-response curves for stimulants, including L-glutamate, NMDA, kainate, and SNP, were constructed to determine the concentrations of the stimulants to be used in further studies. In other slices, after 90 min equilibration, one to two slices from each rat were left untreated (control) and other slices were pretreated for $30 \mathrm{~min}$ with either propofol $(10 \mu \mathrm{M}-1 \mathrm{mM})$, ketamine $(10-100 \mu \mathrm{M})$ or midazolam $(1-100 \mu \mathrm{M})$. The slices were then exposed to L-glutamate ( $3 \mathrm{mM})$ for two minutes, NMDA $(0.1 \mathrm{mM})$, kainate $(0.1 \mathrm{mM})$, or SNP $(0.3 \mathrm{mM})$ for three minutes, and then quick-frozen in liquid nitrogen. Since propofol was in the form of an aqueous emulsion (propofol $1 \%$, soya bean oil $10 \%$, glycerol $2.25 \%$, and egg phosphatide $1.2 \%$ ), 18 slices were treated with Intrafat which contained soya bean oil $10 \%$, glycerol $2.5 \%$, and egg phosphatide $1.2 \%$, at a concentration equivalent to that contained in the propofol emulsion. The levels of cGMP in the slices were measured by radioimmunoassay, using a Yamasa cyclic GMP assay kit (Yamasa Shoyu Co., Chiba, Japan), and protein levels were measured with the Lowry method. Forty-two slices were pretreated with bicuculline methiodide (BMI, $1 \mathrm{mM}$ ), a $\gamma$-aminobutyric acid $(\mathrm{GABA})_{\mathrm{A}}$ receptor antagonist, alone, or with $\mathrm{BMI}$ and propofol, before stimulation with L-glutamate, NMDA and SNP.

The Krebs' bicarbonate solution contained $(\mathrm{mM})$ : $\mathrm{NaCl} 118.2, \mathrm{KCl} 4.6, \mathrm{CaCl}_{2} 2.5, \mathrm{KH}_{2} \mathrm{PO}_{4} 1.2, \mathrm{MgSO}_{4}$ 1.2, $\mathrm{NaHCO}_{3} 24.8$, and dextrose 10. Drugs studied were ketamine (Sigma, St. Louis, MO, USA), midazolam 
(Yamanouchi Pharmaceutical Co., Osaka, Japan), Intrafat (Nihon Pharmaceutical Co., Osaka, Japan), NMDA (Nacalai Tesque, Kyoto, Japan), kainate (Nacalai Tesque), L-glutamate (Nacalai Tesque), SNP (Nacalai Tesque), and BMI (Sigma). Propofol was supplied by Zeneca Pharmaceutical Co. (Osaka, Japan). All drugs were dissolved and diluted with distilled water, and added directly to the bathing fluid; the volume added was $<1 \%$ of the bath.

Data were analysed by Student's t test for unpaired data, or analysis of variance and Fisher's test when appropriate. Data in the text and figures are expressed as means \pm standard error (SE). Differences at $P<0.05$ were considered significant.

\section{Results}

Dose response curves of the effect of L-glutamate, NMDA, kainate and SNP on cGMP production are shown in Figure 2. L-glutamate $(3 \mathrm{mM})$, NMDA $(0.1 \mathrm{mM})$ and kainate $(0.1 \mathrm{mM})$, which induced a submaximal but significant increase in CGMP, were used in the following study. Sodium nitroprusside $(0.3 \mathrm{mM})$ was used in the following study because this concentration increased cGMP level to the same extent with NMDA $(0.1 \mathrm{mM})$.

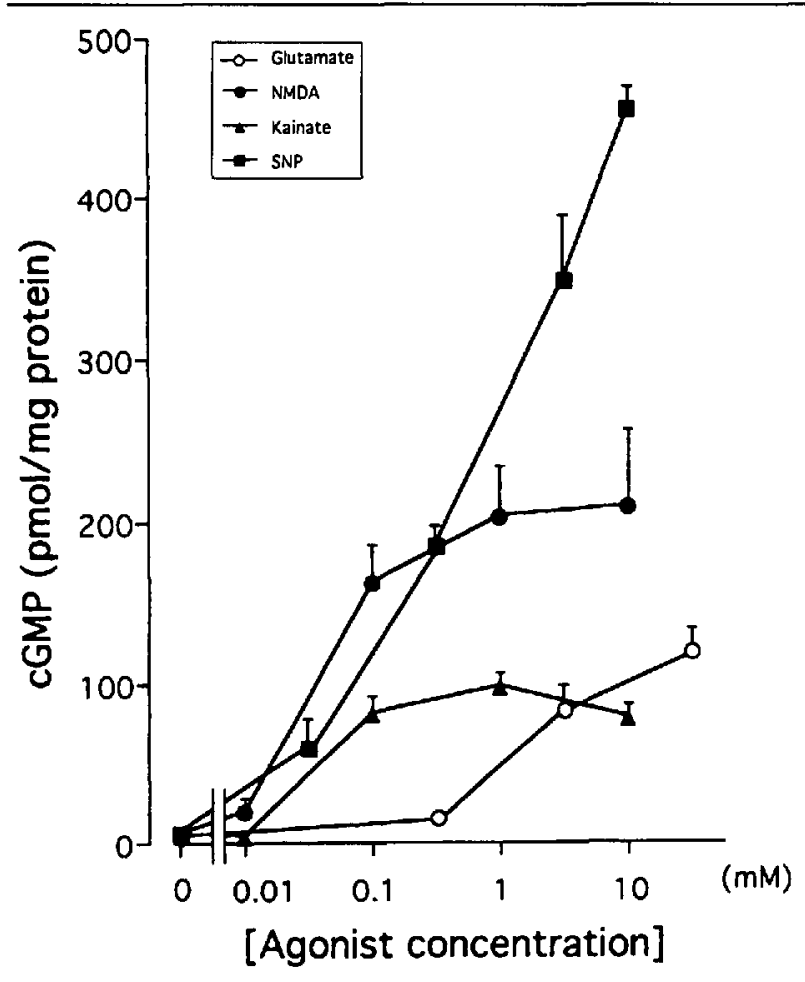

FIGURE 2 The cyclic guanosine monophosphate (cGMP) levels of rat cerebellar slices exposed to glutamate, NMDA, kainate and SNP. $O=$ glutamate; $=$ NMDA; $\boldsymbol{\Delta}=$ kainate; $\boldsymbol{\omega}$ = SNP; $(n=5-8)$.
In the absence of agonists, the maximum concentration of anaesthetics studied did not affect cGMP levels (Figure 3). In contrast, agonist-stimulated levels of cGMP were suppressed by propofol concentrationdependently. NMDA (0.1 mM)-induced cGMP production was suppressed by propofol, $10 \mu \mathrm{M}-1 \mathrm{mM}$, $(P<0.05-0.01)$, kainate $(0.1 \mathrm{mM})$-induced production by $100 \mu \mathrm{M}-1 \mathrm{mM}(P<0.01)$, and L-glutamate (3 $\mathrm{mM})$ - and SNP $(0.3 \mathrm{mM})$ - induced productions by $1 \mathrm{mM}(P<0.05$, Figure 4, 5). Ketamine, $10-100 \mu \mathrm{M}$, strongly suppressed L-glutamate $(3 \mathrm{mM})$ - and NMDA $(0.1 \mathrm{mM})$-induced cGMP production $(P<0.01)$ but did not affect kainate $(0.1 \mathrm{mM})$ - and SNP $(0.3 \mathrm{mM})$-induced productions (Figures 4, 5). Midazolam, 10-100 $\mathrm{MM}$, suppressed kainate $(0.1 \mathrm{mM})$-induced cGMP production $(P<0.05-0.01)$, but did not affect L-glutamate $(3 \mathrm{mM})$, NMDA $(0.1 \mathrm{mM})$ - or SNP $(0.3 \mathrm{mM})$-stimulated cGMP levels (Figure 4,5 ). Intrafat, the solvent of propofol, at a concentration equivalent to $1 \mathrm{mM}$ propofol, had no effect on cGMP levels (data not shown). Treatment with BMI did not alter the L-glutamate (3 mM)-, NMDA (0.1 $\mathrm{mM})$ - and SNP $(0.3 \mathrm{mM})$-stimulated levels of cGMP in this experiment, and propofol $(1 \mathrm{mM})$ suppressed cGMP levels to the same extent in the absence and presence of BMI (see Table on page 1304).

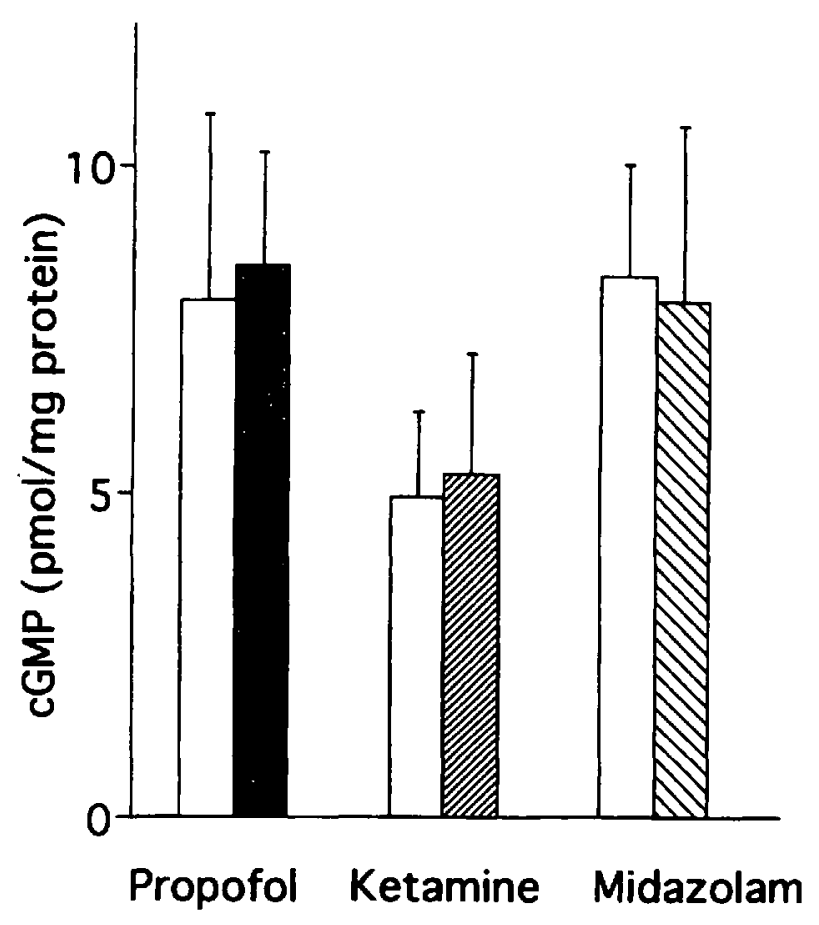

FIGURE 3 The effect of propofol $(1000 \mu \mathrm{M})$, ketamine (100 $\mu M)$ and midazolam $(100 \mu M)$ on cyclic guanosine monophosphate (cGMP) levels of rat cerebellar slices in the absence of stimulants.

$\square=$ control; $\square=$ propofol; $\mathscr{W}=$ = ketamine; $\mathbb{N}$ = midazolam; $(n=5)$. 

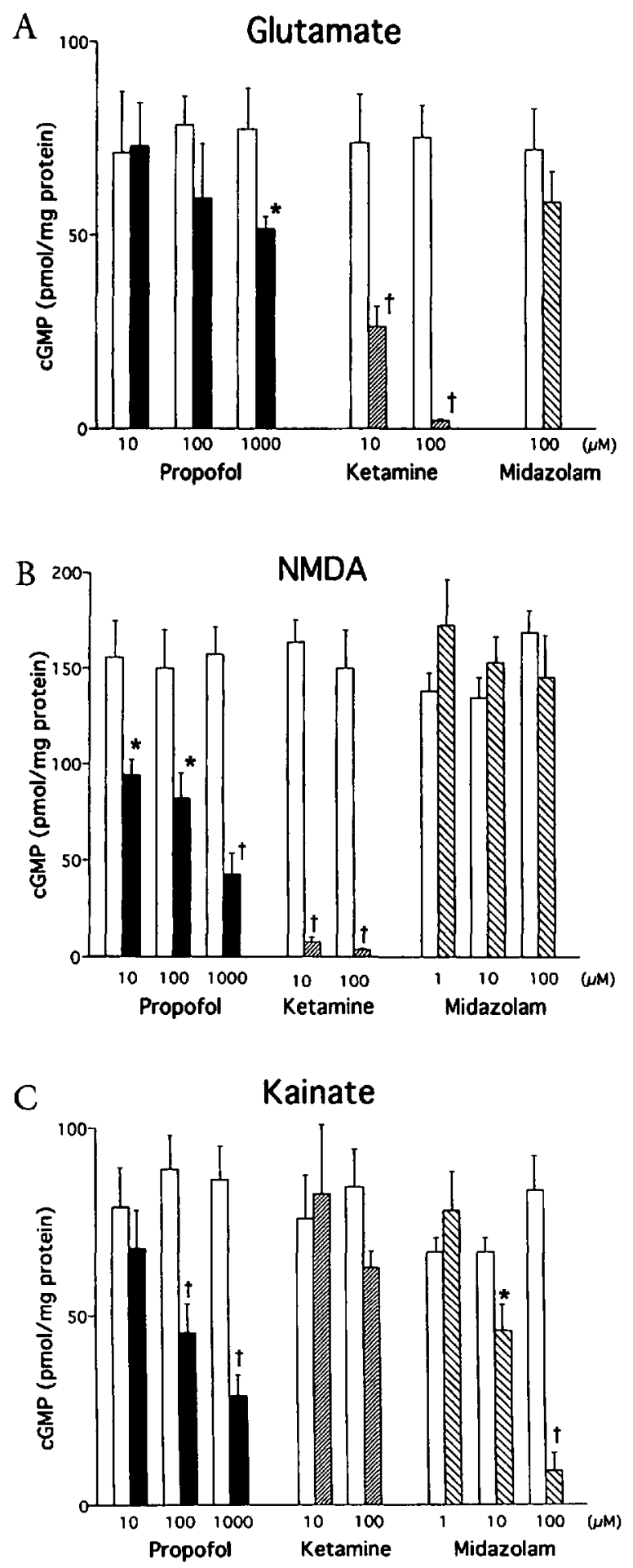

FIGURE 4 The effect of propofol (10-1000 $\mu \mathrm{M})$, ketamine $(10-100 \mu \mathrm{M})$ and midazolam $(1-100 \mu \mathrm{M})$ on cyclic guanosine monophosphate (cGMP) levels of cerebellar slices stimulated with L-glutamate ( $3 \mathrm{mM}, \mathrm{A}$ ), N-methyl-D-aspartate (NMDA, 0.1 $\mathrm{mM}, \mathrm{B})$ and Kainate $(0.1 \mathrm{mM}, \mathrm{C})$

$\square=$ control; $\mathbf{\square}=$ propofol; $\mathbb{V}=$ ketamine; $\mathbb{N}=$ midazolam; ${ }^{*} P<0.05,{ }^{t} P<0.01$ from the corresponding value without pretreatment with anaesthetics (control); $(n=5-11)$.

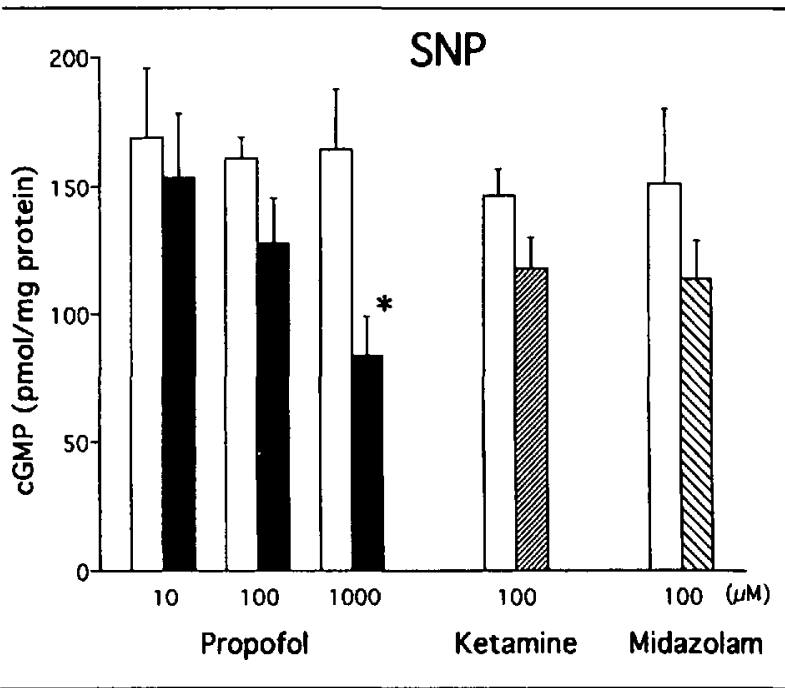

FIGURE 5 The effect of propofol $(10-1000 \mu \mathrm{M})$, ketamine $(100 \mu \mathrm{M})$ and midazolam $(100 \mu \mathrm{M})$ on cyclic guanosine monophosphate (cGMP) levels of cerebellar slices stimulated with sodium nitroprusside (SNP, $0.3 \mathrm{mM}$ ).

$\square=$ control; $\mathbf{\square}=$ propofol; $\mathbb{W}=$ ketamine; $\mathbb{N}$ = midazolam ${ }^{\star} P<0.05$ for difference from the corresponding value without pretreatment with anaesthetics (control); $(n=6-10)$.

\section{Discussion}

The present study showed that, in the absence of individual receptor ligand or NO donor drug, cGMP production was not affected by any of the anaesthetic agents studied. Propofol at concentrations $\geq 10 \mu \mathrm{M}$ suppressed the NMDA-induced response, at concentrations $\geq 100 \mu \mathrm{M}$ the kainate-induced response, and at a high concentration of $1 \mathrm{mM}$ suppressed the L-glutamate- and SNP-induced responses. Ketamine (10-100 $\mu M)$ suppressed the L-glutamate- and NMDA-induced responses, but did not affect those induced by kainate or SNP. Midazolam did not affect the responses induced by L-glutamate, NMDA or SNP, but, at high concentrations (10-100 $\mu \mathrm{M})$, suppressed the kainate-induced response.

TABLE The cyclic guanosine monophosphate (cGMP) levels in cerebellar slices stimulated with L-glutamatc $(3 \mathrm{mM}), \mathrm{N}$-metyl-Daspartate (NMDA, $0.1 \mathrm{mM}$ ) and sodium nitroprusside (SNP, 0.3 $\mathrm{mM}$ ) in the presence of bicuculline methiodide (BMI, $1 \mathrm{mM}$ ), with or without propofol (1 mM)

\begin{tabular}{lcc}
\hline & BMI alone & BMI and propofol \\
\hline L-glutamate $(\mathrm{n}=6)$ & $64.8 \pm 7.4$ & $25.5 \pm 7.6^{\dagger}$ \\
NMDA $(\mathrm{n}=9)$ & $141.0 \pm 20.0$ & $49.0 \pm 12.6^{\dagger}$ \\
SNP $(\mathrm{n}=6)$ & $172.4 \pm 33.6$ & $88.0 \pm 10.9^{\star}$ \\
\hline
\end{tabular}

Values are mean $\pm \mathrm{SE}$

${ }^{*} P<0.05,{ }^{\dagger} P<0.01$ from the corresponding value without propofol. 
When used clinically for the induction of anaesthesia, the plasma concentrations of propofol, ketamine and midazolam are $20-30 \mu \mathrm{M}, 100 \mu \mathrm{M}$, and $1-2 \mu \mathrm{M}$, respectively. ${ }^{21-23}$ More than $95 \%$ of the propofol and midazolam, ${ }^{21,23}$ and $<50 \%$ of the ketamine ${ }^{24}$ are bound to plasma proteins. The present study therefore demonstrated that the concentration of ketamine in the bath solution required to suppress the NMDA-stimulated response was in a clinically-relevant range, and the concentrations of propofol and midazolam were somewhat higher than the range.

The brain, in vivo, has continuous, ongoing, background activity even during sleep and deep anaesthesia. ${ }^{25}$ In contrast, brain slices in vitro have only occasional slow EEG activity resulting from dendritic electrical oscillation, and have little if any background nerve cell activity. This implies that transmitter release is much less frequent in the slices than in the brain, in vivo. Thus, in the present study, we needed to add relatively high concentrations of the exogenous ligands, L-glutamate, NMDA or kainate, to the fluid bathing the slices (Figure 2). It is likely that, under physiological conditions, the actions of these anaesthetics will be different from those seen in the present in vitro study.

Glutamatergic system is regulated by $\mathrm{GABA}_{\mathrm{A}}$-mediated inhibition in vivo; suppression of GABA activity by $\mathrm{GABA}_{\mathrm{A}}$ antagonists, such as BMI, increases glutamatergic activity ${ }^{26}$ and activation of GABAergic system by midazolam, an agonist at the benzodiazepine site of $\mathrm{GABA}_{\mathrm{A}}$ receptor, suppresses the glutamatergic effect. However, in the present experimental conditions, neither BMI, at a high concentration of $1 \mathrm{mM}$, nor midazolam, up to $100 \mu \mathrm{M}$, affected NMDA-induced cGMP formation. It suggests that the GABAergic system was not activated significantly in cerebellar slices under the present condition.

Propofol is also known to enhance the GABA receptor complex. ${ }^{27}$ However, the suppression of glutamatergic cGMP formation by propofol, shown in this experiment, was not affected by BMI, indicating that this effect of propofol was not mediated by activation of the GABAergic system. We speculate that, in cerebellum in vivo, where the GABAergic cells are active, the suppressive effect of propofol on glutamatergic activity may be much stronger than that observed in cerebellar slices and that midazolam may suppress NMDAinduced effect strongly.

Conflicting results have been reported on the effects of intravenous anaesthetics on NOS activity. Tobin and co-workers, ${ }^{17}$ demonstrated that intravenous anaesthetics such as ketamine, midazolam, pentobarbitone and fentanyl, did not modify the activity of NOS obtained from rat cerebellar homogenate. In contrast, Galley and
Webster demonstrated that ketamine, midazolam, thiopentone and etomidate suppressed activity of NOS isolated from rat whole brain. ${ }^{18}$

Interaction of propofol with glutamatergic receptors has been reported by several investigators. An in vivo study using mice showed enhancement of convulsive property of kainate and quisqualate by propofol. ${ }^{28}$ However, in vitro studies demonstrated suppressive effects of propofol on glutamatergic responses. Bianchi and co-workers showed suppression of glutamatedependent $\mathrm{Ca}^{2+}$ entry into rat synaptosomes by propofol. ${ }^{29}$ Yamakura and co-workers showed, using glutamate receptors expressed in Xenopus oocytes, a stronger suppressive effect of propofol on NMDA receptors than on the kainate receptor. ${ }^{30}$

The different sensitivities to propofol between the NMDA- and kainate-induced responses in the present study cannot be explained by the suppression of NOS nor GC activity, but indicate an interaction with NMDA receptor. Although a high concentration of propofol suppressed the SNP-induced response indicating modification of GC activity, the effect of propofol on GC did not play a role in the CNS. These results are in contrast to those in the vascular system, ${ }^{31}$ probably because propofol exerted stronger effects on NMDA receptors than on vascular endothelial acetylcholine receptors.

Gonzales and co-workers demonstrated a selective action of ketamine on NMDA- and AMPA-induced responses, using a primary culture of rat cortical neurons. ${ }^{32}$ The present result with NMDA and kainate is in agreement with this finding, but we could not test the effect on AMPA because AMPA receptor is less abundant in cerebellum of infant rats than in that of adult rats. ${ }^{20}$ Our results indicated that the suppressed formation of cGMP was a result of the action of ketamine on the NMDA receptor, and not due to the direct suppression of the NO-cGMP system.

Surprisingly, midazolam, although at the concentration out of the clinically-relevant range, exerted a stronger suppressive effect on the kainate-induced response than on NMDA-induced response. This clearly indicates an interaction of midazolam with kainate receptors, being in agreement with in vitro findings of Zorumski and co- workers. ${ }^{33}$ The effect of midazolam on L-glutamate-induced effect was not significant, probably because the contribution of NMDA-receptor activation was larger than kainatereceptor activation in L-glutamate-induced cGMP production.

Our previous ${ }^{19}$ and present results revealed that anaesthetic agents suppress glutamatergic receptorlinked cGMP formation by mechanisms different from 
NOS inhibitors. This implies that anaesthetics and NOS inhibitors might act synergistically to suppress excitatory transmission, potentially reducing anaesthetic requirements. Johns and co-workers demonstrated a reduction of minimum alveolar concentration (MAC) of halothane in rats treated with a NO synthase inhibitor, ${ }^{34}$ and Pajewski and co-workers ${ }^{35}$ and Ichinose and co-workers ${ }^{36}$ extended this finding to isoflurane.

However, Adachi and co-workers ${ }^{37,38}$ challenged the above hypothesis. In their experiments, the MAC of halothane was not reduced by NOS inactivation, even when the cerebellar cGMP level was suppressed by chronic intraperitoneal and acute intravenous NOS inhibitor administrations in rats. Moreover, Ichinose and co-workers demonstrated that the isoflurane MAC is not different in mice congenitally deficient in neuronal NOS (knockout mice). ${ }^{36}$

The NO-cGMP pathway has been reported to be involved in the plasticity of CNS functions. ${ }^{6,7}$ Central sensitisation to pain perception is one of the manifestations of CNS plasticity, and pre-emptive analgesia is thought to act by obtunding or blocking establishment of this plasticity. Investigations have not always succeeded, however, in demonstrating the efficacy of the combined use of intraoperative epidural block to reduce postoperative pain in patients receiving general anaesthesia. ${ }^{39}$ This difficulty may be understood by the assumption that general anaesthetics have their own pre-emptive effects ${ }^{40}$ that nullify the effects of local anaesthesia. The suppression of cerebellar cGMP formation by anaesthetics, shown in our previous ${ }^{19}$ and present studies, may support the above assumption, although no direct evidence was obtained.

In summary, NMDA-induced formation of cGMP in rat cerebellar slices was suppressed by propofol and ketamine, and kainate-induced cGMP formation was suppressed by propofol and midazolam. These effects are probably due to an interaction with receptors for excitatory amines, and not to a direct interaction of the drugs with the NO-cGMP system.

\section{References}

1 Furchgott RF, Zawadzki JV. The obligatory role of endothelial cells in the relaxation of arterial smooth muscle by acetylcholine. Nature $1980 ; 288$ : 373-6.

2 Palmer RMJ, Ferrige AG, Moncada S. Nitric oxide release accounts for the biological activity of endothelium-derived relaxing factor. Nature $1987 ; 327$ : 524-6.

3 Ignarro LJ, Byrns RE, Buga GM, Wood KS. Endothelium-derived relaxing factor from pulmonary artery and vein possesses pharmacologic and chemical properties identical to those of nitric oxide radical. Circ Res 1987; 61: 866-79.
4 Garthwaite J, Garthwaite G. Cellular origins of cyclic GMP responses to excitatory amino acid receptor agonists in rat cerebellum in vitro. J Neurochem 1987; 48: 29-39.

5 Garthwaite J, Charles SL, Chess-Williams R. Endotheliumderived relaxing factor release on activation of NMDA receptors suggests role as intercellular messenger in the brain. Nature 1988; 336: 385-8.

6 Shibuki $K$, Okada $D$. Endogenous nitric oxide release required for long-term synaptic depression in the cerebellum. Nature 1991; 349: 326-8.

7 Bliss TVP, Collingridge GL. A synaptic model of memory: long-term potentiation in the hippocampus. Nature $1993 ; 361: 31-9$.

8 Garthwaite J, Garthwaite G, Palmer RMJ, Moncada S. NMDA receptor activation induces nitric oxide synthesis from arginine on rat brain slices. Eur J Pharm 1989; 172: 413-6.

9 Gartbwaite J, Southam E, Anderton $M$. A kainate receptor linked to nitric oxide synthesis from arginine. J Neurochem 1989; 53: 1952-4.

10 Katsuki S, Arnold W, Mittal C, Murad F. Stimulation of guanylate cyclase by sodium nitroprusside, nitroglycerin and nitric oxide in various tissue preparations and comparison to the effects of sodium azide and hydroxylamine. J Cyclic Nucleotide Res 1977; 3: 23-35.

11 Muldoon SM, Hart JL, Bowen KA, Freas W. Attenuation of endothelium-mediated vasodilation by halothane. Anesthesiology 1988; 68: 31-7.

12 Nakamura K, Terasako K, Toda $H$, et al. Mechanisms of inhibition of endothelium-dependent relaxation by halothane, isoflurane, and sevoflurane. Can J Anaesth 1994; 41: 340-6.

13 Toshida $K$, Okabe E. Selective impairment of endothelium-dependent relaxation by sevoflurane: oxygen-free radicals participation. Anesthesiology 1992; 76: 440-7.

14 Uggeri MJ, Proctor GJ, Johns RA. Halothane, enflurane, and isoflurane attenuate both receptor- and nonreceptor-mediated EDRF production in rat thoracic aorta. Anesthesiology 1992; 76: 1012-7.

15 Toda $H$, Nakamura $K$, Hatano $Y$, Nishiwada $M$, Kakuyama $M$, Mori $K$. Halothane and isoflurane inhibit endothelium-dependent relaxation elicited by acetylcholine. Anesth Analg 1992; 75: 198-203.

16 Terasako K, Nakamura K, Toda $H$, Kakuyama $M$, Hatano $Y$, Mori $K$. Barbiturates inhibit endotheliumdependent and independent relaxations mediated by cyclic GMP. Anesth Analg 1994; 78: 823-30.

17 Tobin JR, Martin LD, Breslow MJ, Traystman RJ. Selective anesthetic inhibition of brain nitric oxide synthase. Anesthesiology 1994; 81: 1264-9.

18 Galley HF, Webster NR. Brain nitric oxide synthase activity is decreased by intravenous anesthetics. Anesth Analg 1996; 83: 591-4. 
19 Terasako K, Nakamura K, Miyawaki I, Toda $H$, Kakuyama $M$, Mori $K$. Inhibitory effects of anesthetics on cyclic guanosine monophosphate (cGMP) accumulation in rat cerebellar slices. Anesth Analg 1994; 79: 921-6.

20 Southam E, East SJ, Garthwaite J. Excitatory amino acid receptors coupled to the nitric oxide/cyclic GMP pathway in rat cerebellum during development. J Neurochem 1991; 56: 2072-81.

21 Servin F, Desmonts JM, Haberer JP, Cockshott ID, Plummer GF, Farinotti R. Pharmacokinetics and protein binding of propofol in patients with cirrhosis. Anesthesiology 1988; 69: 887-91.

22 Domino EF, Zsigmond EK, Domino LE, Domino KE, Kothary SP, Domino SE. Plasma levels of ketamine and two of its metabolites in surgical patients using a gas chromatographic mass fragmentographic assay. Anesth Analg 1982; 61: 87-92.

23 Greenblatt DJ, Abernetby DR, Locniskar A, Harmatz $J S$, Limjuco $R A$, Shader $R l$. Effect of age, gender, and obesity on midazolam kinetics. Anesthesiology 1984; 61: 27-35.

24 Dayton PG, Stiller RL, Cook DR, Perel JM. The binding of ketamine to plasma proteins: emphasis on human plasma. Eur J Clin Pharmacol 1983; 24: 825-31.

25 Mori K, Winters WD. Neural background of sleep and anesthesia. Int Anesthesiol Clin 1975; 13: 37-108.

26 Quinlan JE, Davies J. Exitatory and inhibitory responses of Purkinje cells, in the rat cerebellum in vivo, induced by excitatory amino acids. Neurosci Lett 1985; 60: 39-46.

27 Concas A, Santoro G, Mascia MP, Serra M, Sanna E, Biggio $G$. The general anesthetic propofol enhances the function of $\gamma$-aminobutyric acid-coupled chloride channel in the rat cerebral cortex. J Neurochem 1990; 55 : 2135-8.

28 Bansinath $M$, Shukla VK, Turndorf $H$. Propofol modulates the effects of chemoconvulsants acting at GABAergic, glycinergic, and glutamate receptor subtypes. Anesthesiology 1995; 83: 809-15.

29 Bianchi M, Battistin T, Galzigna L. 2,6-diisopropylphenol, a general anesthetic, inhibits glutamate action on rat synaptosomes. Neurochem Res 1991; 16: 443-6.

30 Yamakura T. Sakimura $K$, Shimoji K, Mishina $M$. Effects of propofol on various AMPA-, kainate- and NMDA-selective glutamate receptor channels expressed in Xenopus oocytes. Neurosci Lett 1995; 188: 187-90.

31 Miyawaki 1, Nakamura K, Terasako K, Toda $H$, Kakuyama $M$, Mori K. Modification of endotheliumdependent relaxation by propofol, ketamine, and midazolam. Anesth Analg 1995; 81: 474-9.

32 Gonzales $J M$, Loeb $A L$, Reichard PS, Irvine S. Ketamine inhibits glutamate-, $\mathrm{N}$ methyl-D-aspartate-, and quisqualate-stimulated cGMP production in cultured cerebral neurons. Anesthesiology 1995; 82: 205-13.

33 Zorumski CF, Yamada KA, Price MT, Olney JW. A benzodiazepine recognition site associated with the nonNMDA glutamate receptor. Neuron 1993; 10: 61-7.

34 Johns RA, Moscicki JC, DiFazio CA. Nitric oxide synthase inhibitor dose dependently and reversibly reduces the threshold for halothane anesthesia. A role for nitric oxide in mediating consciousness? Anesthesiology 1992; 77: 779-84.

35 Pajewski TN, DiFazio CA, Moscicki JC, Johns RA. Nitric oxide synthase inhibitors, 7 -nitro indazole and nitro ${ }^{\mathrm{G}}$ - $\mathrm{L}$ arginine methyl ester, dose dependently reduce the threshold for isoflurane anesthesia. Anesthesiology 1996; 85: 1111-9.

36 Ichinose F, Huang PL, Zapol WM. Effects of targeted neuronal nitric oxide synthase gene disruption and nitro $^{\mathrm{G}}$-L-arginine methylester on the threshold for isoflurane anesthesia. Anesthesiology 1995; 83: 101-8.

37 Adachi T, Kurata J, Nakao S, et al. Nitric oxide synthase inhibitor does not reduce minimum alveolar anesthetic concentration of halothane in rats. Anesth Analg 1994; 78: 1154-7.

38 Adachi $T$, Shinomura $T$, Nakao $S$, et al. Chronic treatment with nitric oxide synthase (NOS) inhibitor profoundly reduces cerebellar NOS activity and cyclic guanosine monophosphate but does not modify minimum alveolar anesthetic concentration. Anesth Analg 1995; 81: 862-5.

39 Shir $\Upsilon$, Raja SN, Frank SM. The effect of epidural versus general anesthesia on postoperative pain and analgesic requirements in patients undergoing radical prostatectomy. Anesthesiology 1994; 80: 49-56.

40 O'Connor TC, Abram SE. Inhibitation of nociceptioninduced spinal sensitization by anesthetic agents. Anesthesiology 1995; 82: 259-66. 